\title{
The 2014 European Elections in Romania - Media Frames and Their Implications in the Europeanization Process
}

\begin{abstract}
This paper addresses the implications of the media in two major processes at the EU level - the process of Europeanization and the process of building a European identity. So, it analyses European subjects, by focusing on the visibility and the media framing of these subjects during the 2014 EU Parliament elections.

Recent theoretical studies in the domain show that media could be one of the actors that might be responsible for influencing the Europeanization process - either in the sense of enabling the emergence and functioning of a European public sphere or in the sense of even preventing its birth. Thus, our empirical research aims at investigating the degree of Europeanization of the Romanian media discourse in order to reveal the current situation regarding the public sphere in Romania today.

Since the content analysis indicates a low degree of visibility of the European issues and rather low levels of issue-specific frames that might sustain the development of a mature European identity, we can conclude that media still have to struggle to accomplish the transition from the national level to the European(ized) one.
\end{abstract}

Key words: Europeanization, European identity, media framing, EU Parliament elections.

\section{Introduction}

Studies from the last decade show that the European identity can be fostered through media. The way in which media cover the European subjects, help at sharing common symbols, interests and beliefs, offer support for an active public space facilitates citizens' identification with the EU. In this context, taking into account that Europeanization can exert a strong impact on the national identities within the member states and that media represent one of the main means of getting a closer insight to the EU in general, we can presume that the way in which media cover and frame the European subjects may influence the evolution of the Europeanization process.

The research regarding the European identity is based on Bruter's (2005) classification which referred to three facets of European identity: cultural, civic and instrumental. The cultural theory of the European identity refers to the history of the continent along with its shared values and symbols, the civic aspects imply the citizens' identification with the political, economic and institutional system, as well as the feeling of a sense of commonality with citizens from other

* Doctoral School of Communication, National University of Political Studies and Public Administration, Bucharest, Romania, oana.stefanita@yahoo.com.

** Doctoral School of Communication, National University of Political Studies and Public Administration, Bucharest, Romania, raluca_buturoiu@yahoo.com. 
EU member states. On the other hand, the instrumental factors consist in the perception and evaluation of the potential gains or losses which might result from the EU membership.

In order to analyze the visibility and the media framing of the EU topics, we conducted a quantitative research ${ }^{\mathrm{ii}}$. The research is based on a content analysis of 5084 articles, published during the European election campaign, 25 April-25 May 2014, on two of the main important online news portals in Romania - ziare.com and hotnews.ro (according to the ranking on trafic.ro). The two research questions that guided our approach were: How visible are the news items on EU subjects as compared to other types of news in Romanian media? and How are the European subjects framed in the media and which frames are mainly used by common media discourse?

The framing analysis followed two main directions - one general point of view and one specific approach. So, in order to measure the generic frames, we used the following classification of frames: economic consequences frame; responsibility frame; conflict frame; and human interest frame. Moreover, in order to analyze media's influence in building a European identity, we developed three issue-specific frames: cultural European identity frame, civic European identity frame and instrumental European identity frame.

Thus, the main theoretical foundations of our empirical research focus on the following directions: the process of Europeanization and the need to understand its meaning and implications, the role played by media in the process of building a (European) public sphere, how media frame the events and their effects for the audience, as well as the role played by media in the process of building a European identity.

\section{Understanding Europeanization}

During the last decade, the concept of Europeanization has been the center of numerous studies regarding the European Union and other related fields, among which the European integration process looks like the most controversial one (see, for example, Börzel \& Risse, 2000; Brüggemann \& Kleinen-von Königslöw, 2009; Featherstone, 2003; Flockhart, 2010; Kleinen-von Königslöw, 2012; Radaelli, 2004; Sittermann, 2006). But, although there is such an abundant theoretical and empirical literature in the field, the concept of Europeanization seems to have a prevailing abstract meaning. So, the aim of this part of the paper is to (re)organize the existing approaches that define and label the concept of Europeanization, in such a way as to reduce the salient distance between the abstract understanding of the concept and its implications for common citizens.

The concept of Europeanization has its roots in the early fourteenth and fifteenth century, when people from Europe fought to achieve a "European self-consciousness", that is an understanding of the power relationships against the others - people from other continents (Borneman \& Fowler, 1997, p. 489). Nowadays, the concept seems to refer to its original sense - Europeanization as a concept that defines the struggle of the European Union as an entity to place its influence at a worldwide level. Actually, the notion of power represents the key to understanding the concept of Europeanization, but, as Borneman and Fowler suggest, we should see Europeanization in a moderate way, "as a spirit, a vision and a process", rather than lock our minds in an extremely depressive cycle of "Euro-phoria" and "Europessimism" (1997, p. 510). 
As literature suggests, Europeanization is different from related concepts such as European integration, globalization or internationalization. In this sense, Featherstone (2003, pp. 6-12) shows a useful typology in understanding the meanings correlated to the concept of Europeanization: Europeanization as an historical process; as a matter of cultural diffusion; as a process of institutional adaptation; and as the adaptation of policy and policy processes (see also Sittermann, 2006). As the Featherstone (2003, p. 6) suggests, the first two are maximalist interpretations, which have little or even no direct association with the real impact of the EU, while the other two categories are minimalist and they are more "closely linked to the operations of the European Union". In short, the four typologies could be described as follows: Europeanization as an historical process refers to European efforts of placing European civilization in an influential position - in this case, Europeanization supposes the process in which less advanced countries' struggle to adapt to practices from more economically advanced countries of the region; Europeanization as a transnational cultural diffusion refers to the process of diffusion of cultural norms, patterns and identities on a transnational level all around Europe; Europeanization as institutional adaptation refers to the complex process through which domestic institutions from the member states are permanently adapting to the norms and practices emanating from a direct or indirect pressure of being an European member state; Europeanization as an adaptation of policies and policy processes refers to the process through which the EU actions as a supranational power and influences the member states to develop national policies.

So, the main idea of all these typologies is that Europeanization could be seen as the complex process through which European member states try to adapt or change their national-level strategies in order to become part of the European Union as a powerful economic and political entity. But, despite these important distinctions, the above typologies do not offer cues about the level at which changes are supposed to take place - elite, bureaucratic, constitutional, mass-public levels or about the (good or bad) consequences of these changes on member states.

An approach which helps at understanding the changes that take place during the entire process of Europeanization is that of Radaelli (2004, pp. 3-4). The author suggests that, as complex process of adaptation, Europeanization consists of a spectrum of processes, among which there are: "the construction, the diffusion and the institutionalization of formal and informal rules, procedures, policy paradigms, styles and shared beliefs and norms which are first defined and consolidated in the EU policy process and then incorporated in the logic of domestic (national and subnational) discourse, political structures and public policies". In other words, the author stresses that Europeanization functions as an interactive process which is not limited to domestic responses to the EU - "Europeanization deals with how domestic change is processed". In this sense, the concept of Europeanization seems to cover a large area of interpretation since it refers to the changes adopted by the member states both at a formal and an informal level (see also Cowles, Caporaso, \& Risse, 2001). Thus, Europeanization can be defined as the entire process through which the EU member states adopt and adapt themselves to the EU's political, social, institutional and symbolic rules; Europeanization influences both the visible parts of the nation-states and their invisible sides - culture, values and discourse.

Radaelli $(2004$, p. 4) also stresses the idea that Europeanization as a process should be considered from two approaches: top-down and bottom-up. According to the top-down approach, Europeanization is based on the idea that the EU places a strong pressure on the member states and that this pressure results in reactions and change at the domestic level. On the oth- 
er hand, the bottom-up approach refers to the idea that Europeanization starts from "actors, problems, resources, style, and discourses at the domestic level" and postulates that the EU has the role of changing the main components of this system of interaction, driven by domestic forces. But, as the author suggests, the main challenge when trying to understand the process of Europeanization is to understand what goes on inside this complex process and not to limit the interpretation to the connections between dependent (domestic impact) and independent variables (pressure from the EU). Moreover, he is in favor of the ideas from bottomup studies, which point out that Europeanization covers both "vertical processes (from the EU to domestic politics) and horizontal dynamics" (see also Bulmer \& Radaelli, 2004); in this sense, the EU may provide the context and the social opportunities that are to be used by domestic actors in the process of producing exchanges (of ideas, power, policies, and so on) between each other.

Another valuable approach in understanding Europeanization is the one offered by Olsen (2002). The author suggests that one of the first steps towards understanding Europeanization is to understand what is changing. Thus, he identifies five possible uses of the term: Europeanization seen as changes in external boundaries - Europeanization could take place as the EU expands through enlargement; Europeanization as a development of institutions at the EU level; Europeanization as central penetration of national systems of governance refers to a coordination among all multilevel systems of governance in order to find a balance between unity and diversity; Europeanization as exporting forms of political organization beyond the European borders; Europeanization as a political unification project - the aim of the EU is to become a more unified and stronger political entity in order to be able to face and have an impact on events taking place both inside and outside the EU. As Olsen (2002, p. 940) suggests, while the first four uses of the term refer mainly to institutional, administrative and political aspects, the fifth aspect - that of political unification of Europe seems to be deeply rooted in the real world practices for common citizens. The political unification of Europe could be achieved through the development of a European public sphere which would facilitate the sharing of common conceptions and the development of a sense of belonging, "giving directions to action capabilities".

A more recent conception which concentrates on the process of Europeanization is that of Eriksen (2009, pp. 60-61). The author suggests that, according to the countries' attitude towards the EU, there are three Europeanization options: Europe as a problem solving entity (instrumental rationality); Europe as a value based community (contextual rationality) and Europe as a right based union (communicative rationality). In short, the instrumental rationality refers to the fact that the EU is responsible of solving the perceived problems of the nation-states, among which there are social dislocation, threats to social and welfare arrangements, multi-ethnicity, environmental problems and risks, international crime and security threats; in this case, the efficiency of the EU as an entity depends on its ability to solve problems and to deliver the goods that people demand. The contextual rationality refers to the fact that the EU should function as a community in which different national identities should be in harmony with the European identity; here, the success of the EU depends on the capacity of developing a shared identity and a value basis for integrating divergent conceptions of the good life and a large number of societal interests. The communicative rationality refers to the idea that the $\mathrm{EU}$ is in need of direct legitimation and that this legitimation could be facilitated through active popular participation; in this case, the efficiency of the EU 
refers to its ability to establish a fair system of cooperation founded on democratic procedures for deliberation and decision-making.

Another important conception regarding the process of Europeanization is that of Töller (2004). When characterizing Europeanization, the author refers to three mechanisms: Europeanization by adaptation, Europeanization by learning and Europeanization by evasion. The first two types of Europeanization seem to be the most frequent cases of Europeanization since they imply changes in national policies due to adopting specific positive policies, mostly as directives or regulations or due to learning different perceptions and persuasions, mainly through a policy discourse. On the other hand, the third mechanism of Europeanization refers to cases when EU member states adopt an avoidance strategy towards the norms and regulations coming from the EU; paradoxically speaking, this evasion mechanism is also considered as a part of the process of Europeanization.

As a conclusion, we consider that the above mentioned approaches offer a working conceptual frame through which one could understand Europeanization. Although these approaches are significantly different, they seem to be guided by the idea that the Europeanization of political policies is among the EU's most striking challenges. In this sense, following Olsen's (2002) ideas, the existence and well-functioning of the EU as a political project depends on the creation of a European(ized) public sphere, which could not be possible without the help of a communicative space, facilitated by the media. Thus, in the following section of this paper, we will critically analyze the crucial role played by the media in the whole process of Europeanization.

\section{Europeanization and the media nowadays}

Although our research does not focus on theories regarding the (European) public sphere, we will shortly analyze some key-findings in this domain, since we consider that the study of Europeanization through media could not be otherwise understood in its whole complexity. Thus, in the following lines, we will shortly analyze some theoretical and empirical findings about the role played by media in the process of Europeanization of national public spheres.

One key-approach that analyzes the role played by media in the creation and well-functioning of a public sphere is that of Habermas $(1989,2006)$. As the author suggests, in the contemporary society, mass-media help at organizing and defining the structure of discursive contributions. The force of media derives from its power to organize and structure the information and present it to the public, from its ability to select and make the information flow. Thus, at the public sphere level, media are seen as a legitimate actor that should organize and filter the information that is going to be offered to the general public (see also Lippmann, 1922). More specifically, in this context, it is necessary to mention Habermas' (2009) conception regarding the public sphere at the EU level: the author suggests the need that national public discourses should transform in the sense of coming closer to what Europeanization means. In other words, the author is in favor of the idea that media could proceed in the sense of modifying national public debates into Europeanized ones - through the process of developing European subjects and offering information about similar debates from other EU member states. So, the central position of media and the reciprocal receptivity of national public spheres are two main devices which are indispensable for the well-functioning of the concept of public sphere at the EU level. 
Another valuable approach that concentrates on the role played by media in the process of Europeanization is that of Koopmans and Statham (2010). The authors suggest that the Europeanization of the national public spheres from member states could only be possible if a more significant part of public debate went beyond political national borders, though staying inside EU's borders. In this context, media coverage on national-level issues from other EU member states could be considered a real marker regarding the level of Europeanization of public sphere. Moreover, Koopmans and Pfetsch (2007, p. 67) emphasize the idea that, depending on the density of communication flows, the public sphere from a country could be national, transnational or European (for a better understanding of the concept of European public sphere as an ideal, see Risse, 2003). In this context, media are responsible for the existence of two types of Europeanization of public discourse: vertical Europeanization (refers to media communication linkages between the national and European levels) and horizontal Europeanization (refers to media communication practices limited to the borders of member states).

This distinction between vertical and horizontal Europeanization was one of the most important points of interest for Brüggemann and Kleinen-von Königslöw (2009). The two researchers define Europeanization as a form of transnationalization (for a better understanding of the concept, also see Brüggemann, Kleinen-von Königslöw, \& Sifft, 2004; Brüggemann \& Schulz-Forberg, 2009) limited to the European continent or, more specifically, to the member states of the EU (2009, p. 29) and they develop a model that differentiates among four forms of Europeanization: comprehensive Europeanization, segmented Europeanization, Europeanization aloof from the EU and a parochial public sphere. In short, comprehensive Europeanization refers to high levels of both vertical and horizontal Europeanization; segmented Europeanization refers to the only existence of the vertical dimension - this means high attention to Brussels and no attention to the debates from other member states; Europeanization aloof from the EU refers to the only existence of the horizontal dimension - this means that there is a permanent communicative exchange among the EU member states, while ignoring Brussels and a parochial public sphere refers to the absence of both dimensions due to the fact that national media could not adapt in any way to the new reality where some of the "political competences have been shifted away from national governments and capitals" (2009, p. 30).

According to Brüggemann and Kleinen-von Königslöw (2009, p. 34) the vertical dimension of Europeanization could have two main empirical indicators: the visibility of EU institutions (are EU institutions mentioned in the text?) and the focus on EU politics (are EU politics the main subject of an article?). On the other hand, the two main empirical indicators in the case of the horizontal dimension of Europeanization could be: the focus on other EU countries (are other EU countries the main subject of an article?) and the extended quotes of voices from other EU countries (are speakers from other EU countries quoted in more than one sentence within an article?). As the authors suggest, by comparison with the horizontal dimension, the vertical dimension of Europeanization seems to be registering significant advancement due to the passage of time - one possible explanation is that the visibility of European topics could be more easily operationalized than the reciprocal receptivity among the Europeanized public spheres (see, also, Kleinen-von Königslöw, 2012; Lauristin, 2007).

So, the approaches regarding the vertical dimension of Europeanization of national public spheres seem to refer to two main directions. One of them focuses on the visibility and prominence of European topics as compared to national topics, while the other direction focuses on the perspective used in mediatizing the specific EU topic - or, in other words on the 
way in which media frames the topic. Thus, due to the multitude of studies regarding either of the two directions, we will critically analyze some of the most representative approaches that would be part of our empirical research.

Trenz (2004, pp. 293-294) offers a representative approach regarding the level of Europeanization of political communication. The author suggests that the level of Europeanization of communication can be revealed by the visibility of EU topics in the media; thus, after analyzing a series of significant newspapers from 6 member states, he classifies the articles as follows: European articles (dominated by European topics), Europeanized articles (dominated by national topics, but in which there are some references to one or many European subtopics or issues), articles with a European referential frame (dominated by non-European topics, but in which there are rhetorical references to Europe. Following the same line, Peter and de Vreese (Peter \& de Vreese, 2004, p. 5) suggest that "coverage of the EU can be defined as coverage that addresses EU policies and politics, EU institutions and politicians, or events at the EU level"; they also expect that the visibility of EU topics is different due to their reference to routine or summit periods (when there are scheduled European key events such as European elections, EU referenda, or EU summits). So, their main findings are that there is a reduced level of visibility of EU topics in national media and also a very limited visibility of EU officials (institutional actors), suggestively called "faceless Europe" (2004, p. 17).

Peter and de Vreese's (2004) findings show that the visibility of the EU is higher during summit periods as compared to routine periods (see, also, Schuck, Xezonakis, Elenbaas, Banducci, \& de Vreese, 2011). Similar findings are those of de Vreese (2001) whose study regarding three main events at the EU level - the January 1999 first-step introduction of the euro, the June 1999 European Parliamentary elections, and the December 2000 summit in Nice - reveals that news coverage of European affairs is cyclical, "peaking during the events but hardly visible before and after" (2001, p. 283). Moreover, another term of comparison which could show differences in the visibility of EU topics in national media is the period that has passed since the country's integration in the EU. Thus, studies (de Vreese, Banducci, Semetko, \& Boomgaarden, 2006) talk about the existence of 15 old countries and 10 new countries and emphasize that the visibility of EU related topics is higher within the new member states.

In conclusion, following the ideas from the studies regarding the EU related topics visibility in national media, we are in favor of the idea that a supranational European public sphere could not exist, but that media can still exert a key role in placing EU topics on the public agenda; in other words, national media can still remain the most important way of access to a Europeanized public sphere. As far as the other direction regarding vertical Europeanization is concerned, it includes studies focusing on the way in which media have a key role in forming packages of interpretation or framing the EU related topics (for example, Schuck \& de Vreese, 2006; Semetko, de Vreese, \& Peter, 2000; Vliegenthart, Schuck, Boomgaarden, \& de Vreese, 2008). These studies' idea is that the way in which media frame a European topic may have significant implications in the process of the correct understanding of that specific topic or, in other words, in the whole process of coming closer to what EU refers to. Thus, a detailed analysis regarding the main theoretical approaches towards media framing will be the central part of the next section in this paper. 


\section{Framing as a powerful Europeanization device}

Studies in the domain of the effects that media can exert on public opinion show that media have the ability of shaping audience opinion, mainly through the process of framing. Thus, media could have an important role in developing a common reference frame regarding the $\mathrm{EU}$; then, the audience could use these media reference frames both in a short term period in the process of coming closer to the EU - and in a long term period - in the process of interpreting similar future issues. Moreover, considering that, in general, citizens depend on media when informing about European topics (de Vreese, Peter, \& Semetko, 2001), the way in which media frame an event is of high importance for the audience's correct understanding of that event and for its opinion (re)formation.

Due to the high complexity of the entire process of media framing and its public effects on opinion (re)formation, studies in the domain have known a continuous development (see, for example, Price, Tewksbury, \& Powers, 1997; Scheufele \& Tewksbury, 2007; Scheufele, 2000; Weaver, 2007). Though, taking into consideration our empirical research, we will focus the theoretical approach in this section on some relevant ideas regarding the way in which media frames can exert a (strong) impact on public opinion and on the typology which differentiates between generic news frames and issue-specific news frames.

One of the most cited theories on framing is that of Entman (1993). The author suggests that to frame is to "select some aspects of a perceived reality and make them more salient in a communicating context" (1993, p. 52). Following the same line, Gamson and Modigliani (1987, p. 143) suggest that a frame is "a central organizing idea or story line that provides meaning to an unfolding strip of events [...]. The frame suggests what the controversy is about, the essence of the issue". Moreover, as Gitlin (1980) points out media have an active role in the process of framing, since they package the information for the audiences. Thus, the framing and presentation of events and news in the mass media systematically affect how recipients of the news come to understand these events since frames emphasize certain aspects of reality and abandon others (de Vreese, 2003; Price, Tewksbury, \& Powers, 1995; Scheufele, 1999). So, one common idea of all these definitions of frames and framing is that media act through the process of framing towards shaping the reality for their audiences; in other words, media offer a certain vision towards what is or should be perceived as important by the public.

The above mentioned theories are in favor of the idea that media frames may exert systematic and significant effects in the process of public opinion (re)formation, but another aspect that needs to be mentioned here is that these framing effects could be different according to a typology of framing (for an overview regarding framing typology, see Bennett \& Iyengar, 2010; de Vreese \& Boomgaarden, 2003; Schuck \& de Vreese, 2006; Shah, Kwak, Schmierbach, \& Zubric, 2004; Shehata \& Strömbäck, 2013). That is why, in the following lines we will refer to the typology that separates between generic and issue-specific frames, since it is consistent with our empirical research part.

The typology that separates between generic and issue-specific news frames refers to the nature and content of the frame (de Vreese, 2003, p. 28). In this sense, while issue-specific frames can be used only with regard to specific topics or news events, generic frames transcend thematic limitations and can be identified in relation to different topics, some even over time and in different cultural contexts (de Vreese, 2005). More specifically, issue specific news frames refer to frames that are used in contextual-related or unique situations - these 
frames cannot transcend thematic limitations. On the other hand, generic news frames refer to frames that are not confined to specific topics, to frames that might go beyond thematic limitations and, as de Vreese (2003) suggests, there are two categories of studies examining generic news frames.

The first group of studies concentrates on the coverage of politics, in particular election campaigns (Rhee, 1997). These studies rely on theoretical research that investigates between episodic and thematic news frames (for example, Iyengar, 1991). On the other hand, the second group of studies link news frames to more general features of news coverage such as journalistic conventions, norms and news values (for example, Neuman, Just, \& Crigler, 1992). In the context of the second group of studies, the contribution of Neuman et al. (1992) is essential, since they derived a typology of frames used by the audience when discussing current affairs. So, in an exploratory study, they interviewed audience members and found that that the frames deduced from the interviews were also present in the news media coverage of a series of current issues. Thus, they identified five types of frames used by both the media and the audience: human impact, powerlessness, economics, moral values, and conflict.

In short, the human impact frame refers to descriptions of individuals and groups of individuals that are affected by an issue; the powerlessness frame refers to "the dominance of forces over weak individuals or groups" (1992, p. 67); the economics frame reflects "the preoccupation with the bottom line, profit and loss" (1992, p. 63); the moral values frame refers to the often indirect reference to morality and social prescriptions and the conflict frame refers to the journalistic practice of reporting stories of clashing interpretation and it was found to fit well with news media's "game interpretation of the political world as an ongoing series of contests, each with a new set of winners and losers" (1992, p. 64). These frames were found in relation to different issues which suggest that one main advantage of these frames is that they are more generally applicable than issue-specific news frames - which might be so sensitive to details that they lack the big picture - as it could be described through generic frames (de Vreese, 2003).

Semetko and Valkenburg (2000) developed the line of research initiated by Neuman et al. (1992) and labeled five generic news frames: conflict, human interest, attribution of responsibility, morality and economic consequences. The conflict frame emphasizes conflict between individuals, groups, institutions or countries; the human interest frame brings a human face, an individual's story, or an emotional angle to the presentation of an event, issue or problem; the responsibility frame presents an issue or problem in such a way as to attribute responsibility for causing or solving to either the government or to an individual or group; the morality frame interprets an event or issue in the context of religious tenets or moral prescriptions and, finally, the economic consequences frame presents an event, problem or issue in terms of the economic consequences it will have on an individual, group, institution, region or country.

These theoretical things considered we will focus our empirical research on both issuespecific news frames and generic news frames since our main aim is to get a detailed big picture regarding the media visibility and framing effects of European Parliamentary elections in Romania as a means of analyzing the degree of Europeanization of the national public sphere (see also de Vreese \& Boomgaarden, 2006a, 2006b). In other words, we will use the deductive approach in the study of frames since we are in favor of the idea that the study of framing as an Europeanization device could not be actually done without predefining certain 
frames as content analytic variables in order to check the extent to which these frames occur in the news (Semetko \& Valkenburg, 2000, p. 94).

\section{European identity and its multiple facets}

The concept of European identity was initially introduced on the political agenda in 1973 and since then, there is a growing body of research regarding the roots, the meanings of Europeanness and the subsequent mechanisms that might support the European integration (for example, Goddard, 1994; Stråth, 2002). European identity has been regarded as a key ingredient of the EU integration process, especially in the context of a democratic deficit of the European Union correlated with a growing influence of the EU on citizens' lives (Eriksen, 2005).

Media play an essential role in the processes of identity formation, since they can promote the symbolic material for its maintenance, ensure the visibility of European topics for a sense of European community and for the development of European or Europeanized national public spheres which are interconnected with the concept of European identity (de Vreese, 2007; Koopmans \& Erbe, 2004; Lauristin, 2007; Machill, Beiler, \& Fischer, 2006). What is more, in order to develop a sense of attachment towards the EU, media should increase the presence of the EU in citizens' daily lives (Maier \& Risse, 2003).

Either in the case of self-identity or in that of collective identity (Augoustinos \& Walker, 1995) the feeling of identification with the EU is mostly about adding a sense of Europeanness to established national identities (Gripsrud, 2007). European identity perceived as collective identity implies that "a group of people accept a fundamental and consequential similarity that causes them to feel solidarity amongst themselves" (Fligstein, Polyakova, \& Sandholtz, 2012, p. 108). However, the components of a European identity blend with the national identities and the concept has different meanings for different people (Risse, 2004). The feeling of common identity might also be weaken in times of crisis or if people perceive some inequalities in terms of benefits and obligations (Stråth, 2010). Whichever the case, the EU institutions must strive for developing a common identity since "the success of the EU depends upon developing a shared identity and a value basis for integrating different conceptions of the good life, and a diverse range of societal interests" (Eriksen \& Fossum, 2004, p. 437).

The European identity can be defined from several perspectives such as cultural, civic or instrumental. The cultural perspective analyses the identity as "the sense of belonging an individual citizen feels" (Bruter, 2005, p. 12) and it also includes the cultural heritage of the continent and the common values (Stråth, 2002). The civic perspective sees identities as "the identification of citizens with a political structure, such as a State, which can be defined as the set of institutions, rights, and rules that preside over the political life of a community (Bruter, 2005, p. 12). The civic approach implies the "substance of EU membership", the "commitment to the duties and rights of a civic society" (Jiménez, Górniak, Kosic, Kiss, \& Kandulla, 2004, p. 4). The instrumental approach is based on citizens' calculation in terms of personal interest, on the evaluation of potential gains and losses that come along with being an EU member state. Therefore, if the results of these estimations are positive, especially "compared to the results of policies pursued by national government", then the citizens are more likely "to feel European" (Castiglione, 2009, p. 3).

Based on how people relate to the concept of European identity, they might develop a sense of Europeanness in terms of affiliation towards cultural values, rights, freedoms and ob- 
ligations or just estimated benefits that come with the EU membership. However, positive identification with the EU comes mostly from the benefits granted by the membership status (Fligstein, 2008). In accordance with their support for the Europeanization process, the citizens can be euroenthusiasts, eurosceptics or "instrumental Europeans" when they value only some aspects of the European integrations (Haesly, 2001, p. 82).

Media might play an important role in creating and strengthening individuals' sense of identification with the EU through making the information available, explaining the consequences at societal and individual levels, promoting the common values and symbols and spreading elements that support the identity building process through media frames. All these aspects are empirically tested as part of the analysis included in this article.

\section{The visibility and the media framing of EU topics - research results}

\subsection{Methodology}

In order to analyze the media involvement in the Europeanization process as well as in the process of developing a European identity, we conducted a research on the visibility of European subjects during the 2014 European Parliamentary elections and the main generic and specific frames used in covering these subjects. We performed quantitative research, namely content analysis based on a pre-established grid. The period of time selected for the analysis coincided with the European Parliament campaign, April 25 - May 25, but comprised some other important events such as the geopolitical crisis in Ukraine, the contested referendum in Donetk and Lugansk held by pro-Russia separatists, Romania's public intention to enter the euro zone by the $1^{\text {st }}$ of January 2019 to the authorities in Brussels, the EU visa liberalization for Moldova, the presidential elections in Ukraine.

The corpus of analysis consisted of 5084 news items published in the mentioned time frame on the two main Romanian online news portals (according to the rankings on traffic.ro after eliminating the online versions of newspapers and TV channels): hotnews.ro - 2146 news items and ziare.com - 2938 news items.

The research questions that guided the analysis were:

RQ1: How visible are the news items on EU subjects as compared to other types of news in Romanian media?

RQ2: How are the European subjects framed in the media and which frames are mainly used by common media discourse?

Considering the general context of European Parliamentary elections and the role of media in the Europeanization process, our research wants to determine how visible are the European subjects, which are the main themes and events that captured media's attention. The framing analysis followed two main directions - one general point of view and one specific approach. So, in order to measure the generic frames, we used the following classification of frames: economic consequences frame; responsibility frame; conflict frame; and human interest frame. Moreover, in order to analyze media's influence in building a European identity, we developed three issue-specific frames: cultural European identity frame, civic European identity frame and instrumental European identity frame. 


\subsection{Findings}

\section{a. The visibility of European subjects in the media}

The first axis of the analysis tackles the issue of visibility, specifically the share obtained by the European subjects during the European elections compared to other types of subjects present on the media agenda. The corpus of analysis included 5084 news items, from which $57.8 \%$ were published on ziare.com and $42.2 \%$ on hotnews.ro. The political news were the most present on the agenda $-36.1 \%$, followed by subjects included in the social $-19.8 \%$ and economic areas $-14.7 \%$. The topics were mainly national $-52.7 \%$, international nonrelated to the EU $34.3 \%$ and both national and European topics $7.5 \%$.

Figure 1. Types of subjects.

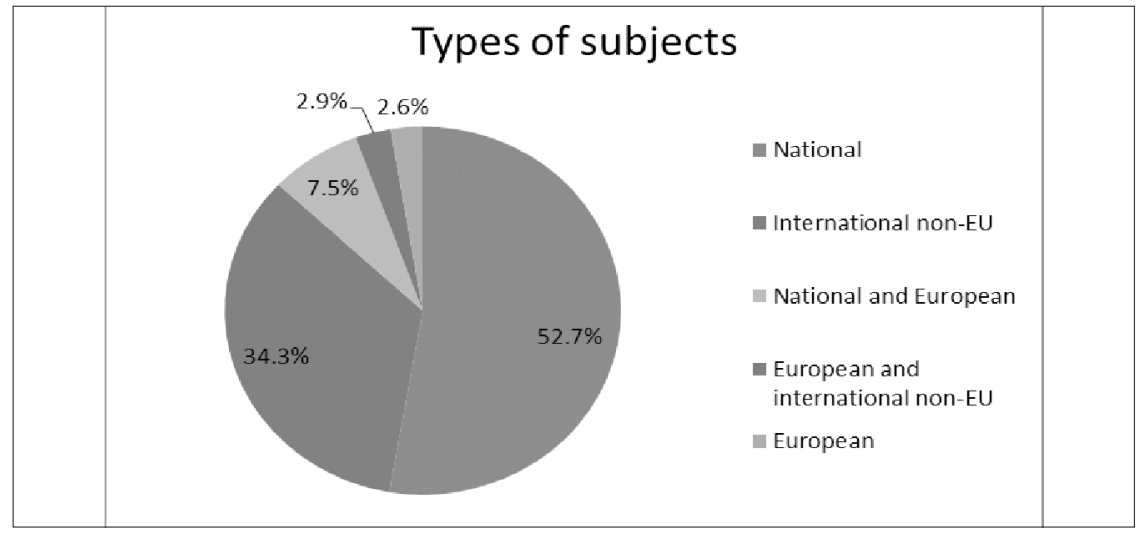

Although the analyzed period coincided with the European campaign for the elections, the European subjects lost their share of visibility on the public agenda detrimental to national concerns and especially to the conflicts in Ukraine. The geopolitical implications of Russia's actions and the crisis generated by pro-Russian separatists in Ukraine had a relative high media exposure with a focus towards the consequences at the level of former soviet countries.

The subjects related to the European Union in all or some aspects, represented 13.1\% from all the published items during the electoral campaign, having a slightly higher percentage on hotnews.ro $-14.9 \%$ than on ziare.com $11.7 \%$. If we look at the media share for European subjects in the previous European electoral campaign in 2009, the average at the level of all 27 states was $20.2 \%$ and for Romania, $12.7 \%$ (Schuck et al., 2011, p. 46). The results for the 2014 EP campaign in Romania, for the analyzed portals, show a slight increase at the level of media coverage of European subjects, but the percentage is still under the European average. Without information about European issues, events, electoral programs, candidates, people can't be active European citizens, can't perform informed decisions, can't support the Europeanization process or feel attached to European values or symbols. Media are a key element in setting the frame for a European(ized) public sphere and for developing a European identity in the future, and without covering matters of possible interest for the EU citizens, without bringing Europe into publics' attention, a common concern or feeling of Europeaness, meaning the existence of a common public debate made possible through a shared European news agenda (Schuck et al., 2011, p. 42), will not have the premises to grow. 
The European subjects were mostly from the political $-70 \%$, economic $-19.6 \%$ and social fields $-5.6 \%$. The main topics were discussing the European elections $-32.2 \%$, the EU's external politics $19 \%$ and European affairs and policies $14.8 \%$. The subjects concerning the elections were more visible on ziare.com $33.9 \%$ compared to hotnews.ro $30.4 \%$. This also applies for the subjects concerning the external politics of the EU and the involvement of EU member states in mediating the conflict in Ukraine $-24.6 \%$ compared to hotnews.ro $-12.9 \%$. On hotnews.ro there was a higher space allocation for European topics that included policies, directives at the level of the EU $-23 \%$, compared to $7 \%$ on ziare.com.

Figure 2. European Topics.

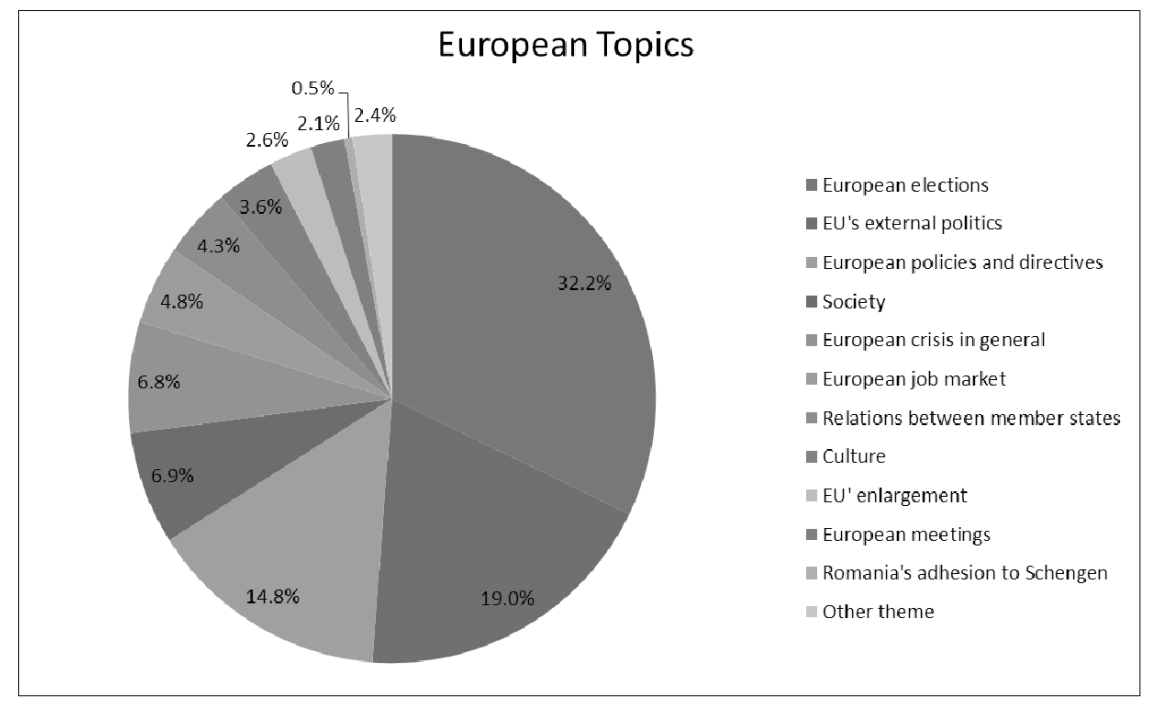

The average number of words allocated for covering a European Subject was 577.8, slightly increased in comparison with the average number of words for the other subjects 394.2. The highest number of words for a European subject was allocated for an interview with the president of the Competition Council discussing a possible European directive regarding the reinvested profit, therefore news with national implications. The focus on national consequences applies to most subjects since the predominant contextualization for European topics is the national one $-47.4 \%$, followed by the European one $-32.4 \%$ and by the international non-EU contextualization $-20.2 \%$. The fact that media still focus only on the national implications when presenting European topics is hindering the Europeanization process by maintaining a low interest towards the consequences and implications at the level of EU as a whole. Without raising an interest for the European space, for the common issues and their aspects at a European level, media will practically prevent the emerging of a common public sphere and of a feeling of affiliation towards the European community. Furthermore, media only tackle the national implications at a very broad level, but the consequences at the level of citizens are merely brought into discussion since only $13.6 \%$ of the European articles include such references. Without information and appropriate understanding of the European consequences in their lives, citizens are unlikely to become more engaged with the European concerns.

In what regards the visibility of the European topics, there were two visibility peaks: on 25 May when 52 European related subjects were published, discussing both the European 
elections poll results and the presidential elections in Ukraine and the possible geopolitical implications at the EU level. The second visibility peak was registered on 12 May when 36 European related topics were published discussing the crisis in Ukraine, the referendum in Donetk and Lugansk held by pro-Russia separatists, the increase in Euroscepticism in the context of a low involvement of EU in solving the crisis between Russia and Ukraine, a crisis that also affects Europe. The visibility of European topics was also high on the $5^{\text {th }}, 6^{\text {th }}$ and $21^{\text {st }}$ of May when, apart from the topics on European campaign, media also approached subjects as the conflict in Ukraine, the proposed sanctions for Russia, the economic implications of the geopolitical crisis especially from the perspective of EU's Russian energy dependence and the implications of Russia-China alliance.

Figure 3. The visibility of European Topics.

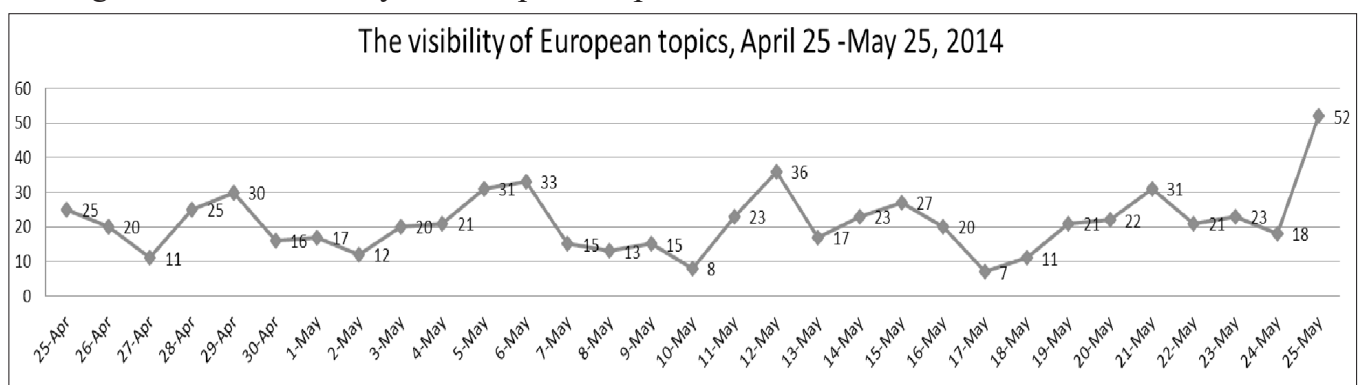

If we consider the visibility of European related topics on each portal, ziare.com covers more the aspects concerning the crisis in Ukraine with the afferent economic and geopolitical implications, while hotnews.ro covers more the elections day and the economic aspects of the Russia-Ukraine conflict.

Figure 4. The visibility of European Topics on each portal.

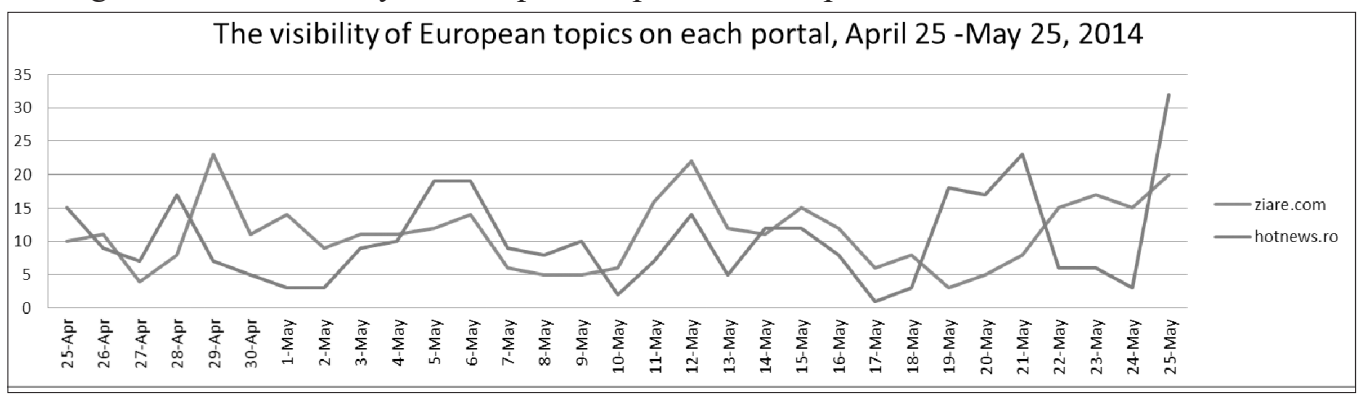

The visibility peaks indicate a high media interest for the crisis involving Russia and Ukraine and for EU's measures and actions in the context of geopolitical effects of the separatist conflicts. Media interest was drawn also by the possible consequences on Moldavia and Romania, especially in the case of increased disputes. These aspects drew the media attention from the European elections which didn't receive an increased coverage in setting the agenda. Also, as we have previously shown, the internal and international non-EU contextualization registered high percentages so the media don't support enough the Europeanization process, not even in the context of the European campaign. 


\section{b. Media framing of European subjects}

Media frames can have an impact on how the image of Europe is being built, how the events are presented and how the elements of a European identity get to be immersed in the common discourse.

In this respect, through media framing analysis we aimed at identifying the most prominent generic and issue-specific frames used in covering the European topics. We used a deductive approach following Holli Semetko and Patti Valkenburg's (2000) criteria for quantifying generic frames: economic consequences frame - if the news refers to financial gains or losses on short or long term, if it includes estimations on involved costs determined by the economic, social or political situation, if it refers to the economic consequences that could derive from adopting or not a set of measures; responsibility frame - if the news suggests that governance structures have the power to alleviate the economic problems, it suggests that the responsibility lies with the government sector or with the policy makers, or if the news suggests taking responsibility for finding solutions to solve the problematic situation; conflict frame - if the news underlines the tendency of a party / individual / group or country to throw the blame on another entity, if the news suggests conflicts among parties, individuals or countries, if there are references to conflicts, disagreements within a party or country, and if the news suggests the existence of pressure groups; human interest frame - if the news refers to the way in which ordinary people are affected, to ordinary people's reactions regarding the events, if the news gives a human face to the subject by using adjectives that suggest sufferance, hardship, humiliation.

We also measured three issue-specific frames to see if media support the development of a European identity by including in the articles elements related to cultural (attachment to Europe and fellow Europeans, common traditions, values and symbols), civic (the feeling of affiliation towards EU as an institutional, economic and political entity, the commitment to the institutional and legal order within which citizens can exercise their rights and duties) and instrumental European identity (the evaluation of EU membership in terms of gains and losses) (Bruter, 2005, Jiménez et al.,2004).

The means for both generic and issue-specific frames can be seen in the table below:

Table 1. Media frames.

\begin{tabular}{|c|c|c|c|c|c|c|c|c|}
\hline \multicolumn{2}{|l|}{ Portal } & $\begin{array}{l}\text { Economic } \\
\text { frame }\end{array}$ & $\begin{array}{l}\text { Respon- } \\
\text { sibility } \\
\text { frame }\end{array}$ & $\begin{array}{l}\text { Conflict } \\
\text { frame }\end{array}$ & $\begin{array}{l}\text { Human } \\
\text { interest } \\
\text { frame }\end{array}$ & $\begin{array}{l}\text { Civic } \\
\text { European } \\
\text { Indentity } \\
\text { frame }\end{array}$ & $\begin{array}{l}\text { Instrumental } \\
\text { European } \\
\text { Identity } \\
\text { Frame }\end{array}$ & $\begin{array}{l}\text { Cultural } \\
\text { European } \\
\text { Identity } \\
\text { frame }\end{array}$ \\
\hline \multirow[t]{3}{*}{ ziare.com } & Mean & 0.12 & 0.12 & 0.15 & 0.10 & 0.19 & 0.15 & 0.06 \\
\hline & $N$ & 345 & 345 & 345 & 345 & 345 & 345 & 345 \\
\hline & Std. Deviation & 0.25 & 0.23 & 0.22 & 0.20 & 0.30 & 0.32 & 0.14 \\
\hline \multirow[t]{3}{*}{ hotnews.ro } & Mean & 0.15 & 0.18 & 0.14 & 0.06 & 0.21 & 0.21 & 0.08 \\
\hline & $\mathrm{N}$ & 319 & 319 & 319 & 319 & 319 & 319 & 319 \\
\hline & Std. Deviation & 0.28 & 0.28 & 0.25 & 0.15 & 0.31 & 0.36 & 0.20 \\
\hline \multirow[t]{3}{*}{ Total } & Mean & 0.13 & 0.15 & 0.14 & 0.08 & 0.20 & 0.18 & 0.07 \\
\hline & $N$ & 664 & 664 & 664 & 664 & 664 & 664 & 664 \\
\hline & Std. Deviation & 0.26 & 0.26 & 0.23 & 0.18 & 0.31 & 0.34 & 0.17 \\
\hline
\end{tabular}


Data for the generic frames do not indicate the clear prevalence of one frame or another. The main used frame was the responsibility one, which registered a mean of 0.15 ( 0 indicates the absence of the frame and 1 indicates its presence in all measured aspects), but the difference from the conflict frame -0.14 or the economic frame -0.13 is almost insignificant. The events that took place in the analyzed period - the European elections, the crisis in Ukraine with its economic and geopolitical implications, the contested referenda held by Russian separatists in Donetk and Lugansk, Romania's intention to enter the euro zone by first January 2019 made public to the authorities in Brussels, the EU visa liberalization for Moldova, the presidential elections in Ukraine, determined close values for the responsibility, conflict and economic frames. Ziare.com framed the topics mainly from a conflict perspective, while hotnews.ro focused on the responsibility angle.

Figure 5. Generic frames.

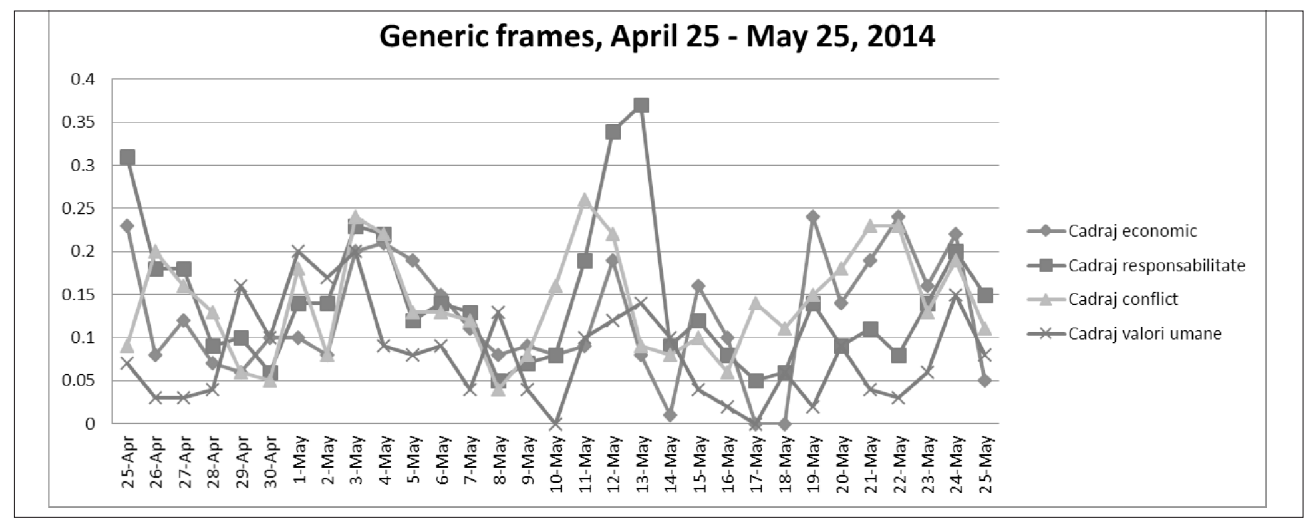

Media used elements of cultural, civic and instrumental identity in covering the European topics during the campaign, supporting thus the development of a European identity. The specific frames had higher means than the generic ones. The predominant frames were the European civic identity -0.20 and the instrumental one -0.18 . The cultural frame had a low value -0.07 , showing thus that the media don't support the Europeanization process in terms of shared culture, values, traditions and common symbols. If we compare the data on the two portals, we can see that hotnews.ro used more elements that can support the European identity and the feeling of affiliation towards the European community.

Figure 6. Issue-specific frames.

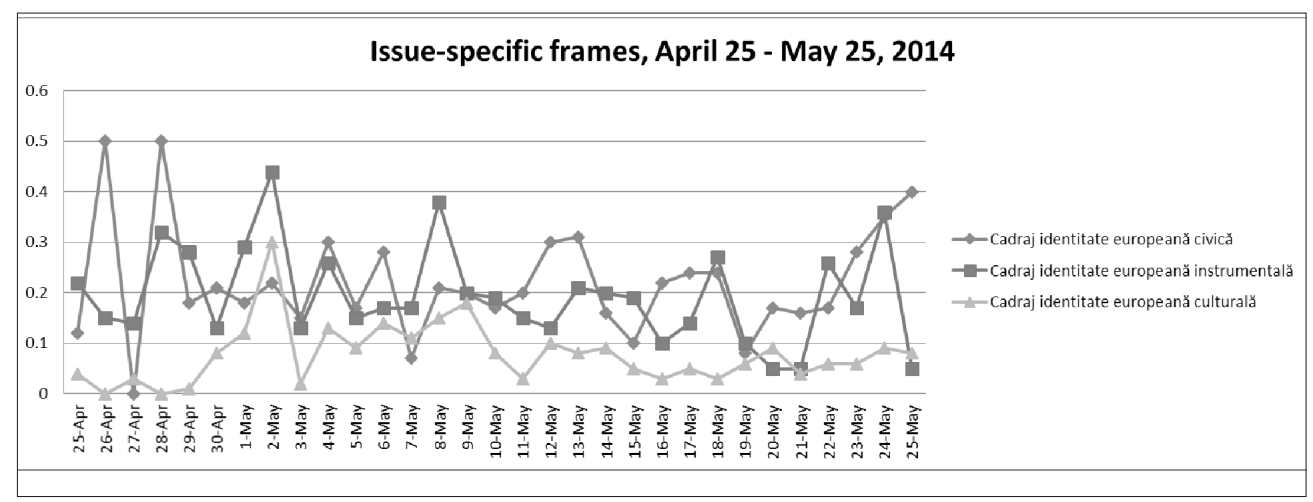


Even though the civic and instrumental frames are present in the media, the support for a European identity is still shy, especially since the analyzed topics were mostly covering the European campaign and the Ukrainian crisis, events that favored an increase in the civic and instrumental terms.

\section{Discussion}

This article successfully shows that the visibility of 2014 EP elections and the way in which European subjects are framed in the news are two key elements which can provide us insightful information regarding the degree of Europeanization of the Romanian public sphere. This research shows that although there is an increasing level of media coverage of European subjects during the 2014 EP elections in Romania, this percentage is still under the European average; this idea is of high importance since it refers to the discussion regarding one major problem at the EU level - the EU's public communication deficit.

Generally speaking, one key finding regarding the visibility of EU related topics in Romanian national media is that they mainly cover national implications when presenting European topics, thus facilitating the existence of a rather national public sphere which still has to struggle to become European(ized). This finding is consonant with the idea that, depending on the communication flows of a country, its public sphere can be national, transnational or European (Koopmans \& Pfetsch, 2007, p. 67). But, more specifically, our analysis shows that although we cannot speak about the existence of a completely working European(ized) public sphere, we may conclude that there is a little more coverage of EU related topics when important events take place.

During the analyzed period, our analysis shows that the visibility of EU subjects in the national media has two peaks: the first one on the $25^{\text {th }}$ of May with 52 articles discussing both the European elections poll results and the presidential elections in Ukraine as well as the possible geopolitical implications at the EU level and the second one on the $12^{\text {th }}$ of May when 36 articles were discussing the crisis in Ukraine, the referendum in Donetk and Lugansk held by pro-Russia separatists, the increase in Euroscepticism in the context of a low involvement of EU in solving the crisis between Russia and Ukraine. Thus, we may presume that during periods when important events take place there is (prominently little) public discourse that might facilitate the emergence of a European(ized) public sphere. As a conclusion, the low visibility of EU related topics on the agenda and the national perspective of European subjects are two findings that favor the idea that media are one of the main responsible actors to be blamed for citizens' low interest regarding the European space since they do not offer them the necessary tools of developing a feeling of affiliation towards the EU.

As far as media framing of the 2014 EP elections, our analysis shows that the three main used generic frames are responsibility, conflict and economic frames; this finding is consonant with our expectations since the events from the analyzed period - the European Parliament elections, the crisis in Ukraine with its economic and geopolitical implications, the contested referenda held by Russian separatists in Donetk and Lugansk, Romania's intention to enter the euro zone by first January 2019 made public to the authorities in Brussels, EU visa liberalization for Moldova, the presidential elections in Ukraine - are causing close values within these three frames. 
From the other perspective, that of issue-specific news frames, we may presume that media were more successful in addressing elements of cultural, civic and instrumental identity when covering the European topics. Thus, in this case, media offered the necessary premises of the development and well-functioning of a European identity, but, even though there are significant civic and instrumental frames in the media, the support for a European identity is still in its infancy.

In conclusion, the results presented in this paper could be seen as a starting point in analyzing the key role of national media in the process of Europeanization of public spheres. Both the degree of visibility of EU related topics on the agenda and the way in which they are framed contribute to the correct understanding of the EU related events, that is they facilitate the process of coming closer or going away from the EU. In Romania, the media content analysis of the 2014 EU Parliament elections shows that national online media still have to struggle to build such a discourse as to encourage the emergence of a European(ized) public sphere.

\section{Notes}

i This work was possible with the financial support of the Sectoral Operational Programme for Human Resources Development 2007-2013, co-financed by the European Social Fund, under the project number POSDRU/159/1.5/S/134650 with the title „Doctoral and Postdoctoral Fellowships for young researchers in the fields Political, Administrative Sciences, Communication Sciences and Sociology“

ii The data reported in this article were collected within the research project - "The European elections 2014 - from media framing to interpersonal conversations agenda. Building the European Identity", coordinated by Nicoleta Corbu and Oana ?tefani?ă, 7 April - 10 June 2014.

\section{References}

Augoustinos, M., \& Walker, I. (1995). Social Cognition: An Integrated Introduction. London: Sage Publications.

Bennett, L. W., \& Iyengar, S. (2010). The Shifting Foundations of Political Communication: Responding to a Defense of the Media Effects Paradigm. Journal of Communication, 60(1), 35-39.

Borneman, J., \& Fowler, N. (1997). Europeanization. Annual Review of Anthropology, 26, 487-514.

Börzel, T. A., \& Risse, T. (2000). When Europe Hits Home: Europeanization and Domestic Change. European Integration Online Papers, 4(15).

Brüggemann, M., \& Kleinen-von Königslöw, K. (2009). 'Let's Talk about Europe': Why Europeanization Shows a Different Face in Different Newspapers. European Journal of Communication, 24(1), 27-48.

Brüggemann, M., Kleinen-von Königslöw, K., \& Sifft, S. (2004). EU Democracy and the Transnationalization of Public Spheres. Presented at the Second Pan-European Conference, Bologna.

Brüggemann, M., \& Schulz-Forberg, H. (2009). Becoming Pan-European??: Transnational Media and the European Public Sphere. International Communication Gazette, 71(8), 693-712.

Bruter, M. (2005). Citizens of Europe? The Emergence of a Mass European Identity. Basingstoke: Palgrave Macmillan.

Bulmer, S. J., \& Radaelli, C. M. (2004). The Europeanisation of National Policy? Queen's Papers on Europeanisation, Oxford.

Castiglione, D. (2009). Political Identity in a Community of Strangers. In J. T. Checkel \& P. J. Katzenstein (Eds.), European Identity. Cambridge: Cambridge University Press. 
Cowles, M. G., Caporaso, J., \& Risse, T. (2001). Europeanization and Domestic Change. Introduction. In M. G. Cowles, J. Caporaso, \& T. Risse (Eds.), Europeanization and Domestic Change. Transforming Europe. Ithaca: Cornell University Press.

De Vreese, C. H. (2001). Europe in the News: A Cross-National Comparative Study of the News Coverage of Key EU Events. European Union Politics, 2, 283-307.

De Vreese, C. H. (2003). Framing Europe?: Television News and European Integration (Dissertation). University of Amsterdam, Faculty of Social and Behavioural Sciences.

De Vreese, C. H. (2005). News Framing: Theory and Typology. Information Design Journal + Document Design, 13(1), 48-59.

De Vreese, C. H. (2007). The EU as a Public Sphere. Living Rev. Euro. Gov, 2(3). Retrieved from www.livingreviews.org/lreg-2007-3

De Vreese, C. H., Banducci, S. A., Semetko, H. A., \& Boomgaarden, H. G. (2006). The News Coverage of the 2004 European Parliamentary Election Campaign in 25 Countries. European Union Politics, 7(4), 477-504.

De Vreese, C. H., \& Boomgaarden, H. G. (2003). Valenced News Frames and Public Support for the EU: Linking Content Analysis and Experimental Data. Communication, 3(4), 361-381.

De Vreese, C. H., \& Boomgaarden, H. G. (2006a). Media Effects on Public Opinion about the Enlargement of the European Union. Journal of Common Market Studies, 44(2), 419-436.

De Vreese, C. H., \& Boomgaarden, H. G. (2006b). Media Message Flows and Interpersonal Communication. The Conditional Nature of Effects on Public Opinion. Communication Research, 33(1), 19-37.

De Vreese, C. H., Peter, J., \& Semetko, H. A. (2001). Framing Politics at the Launch of the Euro: A CrossNational Comparative Study of Frames in the News. Political Communication, 18, 107-122.

Entman, R. M. (1993). Framing: Toward Clarification of a Fractured Paradigm. Journal of Communication, 43(4), 51-58.

Eriksen, E. O. (2005). An Emerging European Public Sphere. European Journal of Social Theory, 8(3), 241-363.

Eriksen, E. O. (2009). The Unfinished Democratization of Europe. Oxford: Oxford University Press.

Eriksen, E. O., \& Fossum, J. E. (2004). Europe in Search of Legitimacy: Strategies of Legitimation Assessed. International Political Science Review, 25(4), 435-459.

Featherstone, K. (2003). Introduction: In the Name of “Europe.” Retrieved from http://ceses.cuni.cz/ceses93-version1-2_2_1.pdf

Fligstein, N. (2008). Euroclash. The EU, European Identity, and the Future of Europe. New York: Oxford University Press.

Fligstein, N., Polyakova, A., \& Sandholtz, W. (2012). European Integration, Nationalism and European Identity. Journal of Common Market Studies, 50(1), 106-122.

Flockhart, T. (2010). Europeanization or EU-ization? The Transfer of European Norms across Time and Space. Journal of Common Market Studies, 48(4), 787-810.

Gamson, W. A., \& Modigliani, A. (1987). The changing Culture of Affirmative Action. In R. G. Braungart \& M. M. Braungart (Eds.), Research in Political Sociology (Vol. 3, pp. 137-177). Greenwich, CT: JAI Press.

Gitlin, T. (1980). The Whole World is Watching: Mass Media in the Making \& Unmaking of the New Left. Berkeley: University of California Press.

Goddard, V. A. (1994). The Anthropology of Europe: Identification and Boundaries in Conflict. (V. A. Goddard, J. R. Llobera, \& C. Shore, Eds.). Oxford: Berg.

Gripsrud, J. (2007). Television and the European Public Sphere. European Journal of Communication, 22(4), 479-492.

Habermas, J. (1989). The Structural Transformation of the Public Sphere. An Inquiry into a Category of Bourgeois Society. (T. Burger, Trans.). Cambridge: MIT Press.

Habermas, J. (2006). The Public Sphere: An Encyclopedia Article. In M. G. Durham \& D. M. Kellner (Eds.), Media and Cultural Studies: Keywords. UK: Blackwell Publishing LTD. 
Habermas, J. (2009). Europe. The Faltering Project. (C. Ciaran, Trans.). Cambridge: Polity Press.

Haesly, R. (2001). Euroskeptics, Europhiles and Instrumental Europeans - European Attachment in Scotland and Wales. European Union Politics, 2(1), 81-102.

Iyengar, S. (1991). Is Anyone Responsible? How Television Frames Political Issues. Chicago: University of Chicago Press.

Jiménez, A. M. R., Górniak, J. J., Kosic, A., Kiss, P., \& Kandulla, M. (2004). European and National Identities in EU's Old and New Member States: Ethnic, Civic, Instrumental and Symbolic Components. European Integration Online Papers, 8(11).

Kleinen-von Königslöw, K. (2012). Europe in Crisis? Testing the Stability and Explanatory Factors of the Europeanization of National Public Spheres. International Communication Gazette, 74(5), 443-463.

Koopmans, R., \& Erbe, J. (2004). Towards a European public sphere? Vertical and horizontal dimensions of Europeanized political communication. Innovation, 17(2), 97-118.

Koopmans, R., \& Pfetsch, B. (2007). Towards a Europeanised Public Sphere? Comparing Political Actors and the Media in Germany (ARENA Report No. 02/2007). Oslo.

Koopmans, R., \& Statham, P. (2010). The Making of a European Public Sphere: Media Discourse and Political Contention. USA: Cambridge University Press.

Lauristin, M. (2007). The European Public Sphere and the New Social Imaginary of the New Europe. European Journal of Communication, 22(4), 397-412.

Lippmann, W. (1922). Public Opinion. New York: The Macmillian Company.

Machill, M., Beiler, M., \& Fischer, C. (2006). Europe-Topics in Europe's Media. The Debate about the European Public Sphere: A Meta-Analysis of Media Content Analyses. European Journal of Communication, 21(1), 57-88.

Maier, M. L., \& Risse, T. (2003). Europeanization, Collective Identities and Public Discourses (IDNET Final Report). Florence: European University Institute.

Neuman, W. R., Just, M. R., \& Crigler, A. N. (1992). Common Knowledge: News and the Construction of Political Meaning. USA: University of Chicago Press.

Olsen, J. P. (2002). The Many Faces of Europeanization. Journal of Common Market Studies, 40(5), 921-952.

Peter, J., \& de Vreese, C. H. (2004). In Search of Europe. A Cross-National Comparative Study of the European Union in National Television News. Press/Politics, 9(4), 3-24.

Price, V., Tewksbury, D., \& Powers, E. (1995). Switching Trains of Thought: The Impact of News Frames on Readers' Cognitive Responses. Presented at the Annual Conference of the Mid-West Association for Public Opinion Research, Chicago, IL.

Price, V., Tewksbury, D., \& Powers, E. (1997). Switching Trains of Thoughts: The Impact of News Frames on Readers' Cognitive Responses. Communication Research, 24(5), 481-506.

Radaelli, C. M. (2004). Europeanisation: Solution or Problem? European Integration Online Papers, 8(16).

Rhee, J. W. (1997). Strategy and Issue Frames in Election Campaign Coverage: A Social Cognitive Account of Framing Effects. Journal of Communication, 47(3), 26-48.

Risse, T. (2003). An Emerging European Public Sphere? Theoretical Clarifications and Empirical Investigations. Presented at the Annual Meeting of the EUSA, Nashville, TN.

Risse, T. (2004). European Institutions and Identity Change: What Have We Learned? In R. Herrmann, M. Brewer, \& T. Risse (Eds.), Identities in Europe and the Institutions of the European Union. Lanham MD: Rowman \& Littlefield.

Scheufele, D. A. (1999). Framing as a Theory of Media Effects. Journal of Communication, 49(1), 103-122.

Scheufele, D. A. (2000). Agenda-Setting, Priming, and Framing Revisited: Another Look at Cognitive Effects of Political Communication. Mass Communication and Society, 3(2-3), 297-316.

Scheufele, D. A., \& Tewksbury, D. (2007). Framing, Agenda Setting, and Priming: The Evolution of Three Media Effects Models. Journal of Communication, 57(1), 9-20.

Schuck, A. R. T., \& de Vreese, C. H. (2006). Between Risk and Opportunity - News Framing and its Effects on Public Support for EU Enlargement. European Journal of Communication, 21(5). 
Schuck, A. R. T., Xezonakis, G., Elenbaas, M., Banducci, S. A., \& de Vreese, C. H. (2011). Party Contestation and Europe on the News Agenda: The 2009 European Parliamentary Elections. Electoral Studies, $30,41-52$.

Semetko, H. A., de Vreese, C. H., \& Peter, J. (2000). Europeanised Politics - Europeanised Media? European Integration and Political Communication. West European Politics, 23(4), 121-141.

Semetko, H. A., \& Valkenburg, P. M. (2000). Framing European Politics: A Content Analysis of Press and Television News. Journal of Communication, 50(2), 93-109.

Shah, D. V., Kwak, N., Schmierbach, M., \& Zubric, J. (2004). The Interplay of News Frames on Cognitive Complexity. Human Communication Research, 30, 102-120.

Shehata, A., \& Strömbäck, J. (2013). Not (Yet) aNew Era of Minimal Effects: A Study of Agenda Setting at the Aggregate and Individual Levels. The International Journal of Press/Politics, 18(2), 234-255.

Sittermann, B. (2006). Europeanisation - A Step Forward in Understanding Europe?

Stråth, B. (2002). A European Identity. To the Historical Limits of a Concept. European Journal of Social Theory, 5(4), 387-401.

Stråth, B. (2010). Introduction. Europe as a Discourse. In B. Stråth \& P. Lang (Eds.), Europe and the Other and Europe as the Other. Brussels: P.I.E. Peter Lang.

Töller, A. E. (2004). The Europeanization of Public Policies - Understanding Idiosyncratic Mechanisms and Contingent Results. European Integration Online Papers, 8(9). Retrieved from http://www.eiop.or.at/eiop /texte/2004-009.htm.

Trenz, H. J. (2004). Media Coverage on European Governance?: Exploring the European Public Sphere in National Quality Newspapers. European Journal of Communication, 19(3), 291-319.

Vliegenthart, R., Schuck, A. R. T., Boomgaarden, H. G., \& de Vreese, C. H. (2008). News Coverage and Support for European Integration, 1990-2006. International Journal of Public Opinion Research, 20(4), 415-439.

Weaver, D. H. (2007). Thoughts on Agenda Setting, Framing, and Priming. Journal of Communication, 57(1), $142-147$. 